\title{
Effects of Biological Systems on Metallic Gold
}

\author{
ITS DISSOLUTION BY ORGANIC SUBSTANCES OF NATURAL ORIGIN
}

\section{William S. Rapson}

International Gold Corporation Ltd., Johannesburg, South Africa

Some fifty years ago, Freise (1) reported a number of observations on the transport of gold by underground water charged with organic material formed by the decomposition of vegetable matter. His interest in this had been aroused by the experience of many persons and companies, who had worked alluvial gold deposits in Brazil, that gold placers which had been thoroughly processed could, after a period of years, be reworked to give a further yield of newly accumulated gold. Freise had been able to confirm this finding from his own experience on two occasions. On each of these, the opening up of a placer deposit, which had been exhausted about 15 years previously, disclosed new accumulations of gold near base-rock level. The new gold was, however, different from the original placer gold in colour, purity, fineness and affinity for mercury.

In fact, the newly deposited gold was very similar in character to the so-called 'black gold' or ouro preto, which was encountered in many districts in Brazil. This consisted of fine gold particles covered with a dark brown to dull black coating 2 to $25 \mu \mathrm{m}$ in thickness. The coating could usually be removed by washing with a 5 per cent solution of potassium carbonate at 35 to $45^{\circ} \mathrm{C}$, although in some cases, where it was thicker, heating to 300 to $330^{\circ} \mathrm{C}$ followed by washing with dilute sulphuric acid was necessary, because of an appreciable content of iron in the essentially organic coating.

These facts suggested that 'black gold' deposits might be formed as a result of the dissolution of gold in water at higher levels by humic substances derived from decaying vegetable matter and its subsequent precipitation from this water at lower levels.

Freise conducted a series of experiments to test this hypothesis and was able to demonstrate not only the ability of water containing humic materials to dissolve gold (and other metals such as iron, copper and manganese) under anaerobic conditions, but also the precipitation of the dissolved metals along with the humic material when the solution containing them was exposed to air. He concluded that these processes played a role in the formation of gold deposits, especially under the conditions prevailing over vast areas of Brazil, where the ground water is characteristically heavily loaded with humic substances from decaying vegetation.

These observations ate intriguing in view of the resistance of gold to attack in so many apparently more aggressive environments, and it may be significant in view of what follows that the 'humic material' used by Freise in his in vitro experiments contained 1.23 per cent of nitrogen.

Interest in the ability of plants to take up gold dates back to the turn of the century and the subject has recently been reviewed by Girling and Peterson (2). Investigators, both in North America and Russia, have recorded higher than normal concentrations of gold in a number of species of plants when collected over areas of gold mineralization, where the metal is present in the soil essentially in elemental form and must therefore be rendered soluble before it can be assimilated. Evidence that such dissolution occurs, through the agency of substances derived either from the plants themselves or from mictoorganisms in the soil, has accumulated in recent years.

Thus, it has been found (3) that the ability of a number of plants to take up gold present in elemental form in the soil is directly related to their ability to release cyanide present in their tissue in cyanogenic glycosides. Parès and her co-workers in Senegal, and subsequently Korobushkina and Mineev and their collaborators in Russia have demonstrated, however, that this may not be the only factor involved.

Parès and his co-workers, for example, found that a number of micro-organisms isolated by them from auriferous deposits were capable of bringing about the slow dissolution of elemental gold both in these deposits and in vitro (4 to 8). They mooted and studied the possibility that gold might be recovered from certain ores by a bacterial leaching process.

Kotobushkina, Mineev et al. ( 9 to 15) were able to confirm these observations in other contexts and have demonstrated that the ability of the active mictoorganisms to dissolve gold is related to their ability to produce extracellular amino acids. A characteristic feature of those organisms examined was a high content of amino acids such as glycine, alanine, serine, aspartic acid and glutamic acid in the media in which they were grown. These authors found that the dissolution of gold by the organisms was increased by the addition to the cultures of an oxidizing agent such as, sodium peroxide and by the selective breeding of more active strains. They also concluded from IR studies that the gold was dissolved as a result of formation between it and the amino acids of complexes which involved Au-N bonds. As an extension of these studies Mineev et al. (16) investigated and reported upon the use of protein hydrolysates, both alone and together with cyanide, for the leaching of gold from 'refractory' ores.

It will be apparent from the above that materials of biological origin can play significant roles in the dissolution, transport and subsequent concentration of gold in shallow occurrences of the metal.

It is possible also that dissolution of gold by the action of amino acids or related substances may be one of the causes of the staining of the skin by gold jewellery. This is an effect which is uncommon and reportedly experienced only by certain individuals, even when wearing high caratage jewellery which is resistant to corrosion under most conditions. The mechanism involved has not yet been systematically studied, and staining has usually been attributed to the formation of fine metallic particles by abtasion. In the light of the above, however, it is not impossible that in cases of individuals with whom such skin darkening apparently arises as a physiological 'abnormality', the fine metallic particles result from 
the sectetion in the perspiration of amino acids or related compounds in concentrations sufficient to dissolve gold with the formation of complexes which subsequently undergo reduction to the metal.

\section{References}

1 F. W. Freise, Econ. Geol., 1931, 26, (4), 421-431

2 C. A. Girling and P. J. Peterson, Gold Bull., 1980, 13, (4), 151-157

3 C. A. Girling and P. J. Peterson, Trace Sub. Environ. Health, 1978, 12, $105-118$

4 Y. Parès and R. Martinet, Bull. Bur. Rech. Geol. Minières, 1964, No. 3, 1-29

5 Y. Parès, Ann. Inst. Pasteur, 1964, 107, 5-10, 132-135, 136-141 and $141-143$

6 Y. Parès and J. Cuper, Ann. Inst. Pasteur, 1964, 107, 568-572

7 Y. Parès and J Girand, Ann. Inst. Pasteur, 1964, 107, 576-577
8 Y. Parès et al., Ann. Inst. Pasteur, 1965, 108, 674-681 and 815-819

9 E. D. Korobushkina, A. S. Chernyak and G. G. Mineev, Mikrobiologiya, 1974, 43, 49-54

10 E. D. Korobushkina, Bıol. Mikroorg. I ikh Ispol'z u Nar. Kh-ve, 1975 , $122-126$

11 E. D. Korobushkina, A. S. Chernyak, G. G. Mineev and E. K. Rodchenko, Biol. Mikroorg, i ikh Ispol'z u Nar. Kh-ve, 1976, 208-219

12 E. D. Korobushkina, G. G. Mineev and G. P. Ptaded, Mikrobiologiya $1976,45,535-538$

13 E. D. Korobushkina and A. B. Gukasyan, in 'The Biology of Heterotrophic Microorganisms', Izd. Im-ta Lesa i Drevesiny Im., V. N. Sukacheva SO Akad. Nauk S.S.S.R., Krasnoyarsk, 1977, 77

14 E. D. Korobushkina, L. L. Zav' yalova and I. M. Korobushkina, Izv. Akad. Nauk. S.S.S.R., Izv. Ser. Biol., English transl., 1977, 6, 772-775

15 E. D. Korobushkina, G. G. Mineev and A. S. Chernyak, U.S.S.R. Patent 35 1884 (1970)

16 G. G. Mineev, T. S. Syrtlanova and I. K. Skobeev, Soviet Non-Ferrous Met. Res., 1977, 5, (6), 213-215 